\title{
The Influence of an 8-Week High-Intensity Interval Training Toward VO2Max
}

\author{
Mia Kusumawati*, Dindin Abidin, Arief Darmawan, Septian Ruswadi \\ Physical Education Department \\ Islamic University 45 \\ Bekasi, Indonesia \\ *miasubarno@gmail.com,dindinabidin70@gmail.com, arief.fik.um@gmail.com, tian_ruswadi@yahoo.com
}

\begin{abstract}
This research wants to know; 1) an effect of 8 weeks HIIT on VO2Max of student as extracurricular participant futsal in Junior High School Budi Mulia Jakarta, 2) an increasing of VO2Max of student as extracurricular participant futsal in Junior High School Budi Mulia Jakarta through HIIT during 8 weeks. This research uses quasi experiment by research design of One-Group Pretest-Posttest. The researcher gives a treatment in the form of HIIT during 8 weeks in 3 times frequency per week. We measure VO2Max in initial and final of training by using Bleep Test to know the changing. The researcher uses SPSS 22 to analyse statistically the data obtained. The results showed an increase, that is the mean pre-test value is $28,9333 \mathrm{ml} \cdot \mathrm{kg}-1 \cdot \mathrm{min}-1$ and after being given training, it increased to $31,4042 \mathrm{ml} \cdot \mathrm{kg}-1 \cdot \min -1(8,54 \%)$. While the test uses paired t-test was obtained significant result as much 0,000 , in other word $p$-value is $<\mathbf{0 , 0 5}$. Based on the results of the study indicated that there are differences VO2Max on student as extracurricular participant futsal in Junior High School Budi Mulia Jakarta after being given HIIT.
\end{abstract} futsal

Keywords: high-intensity interval training (HIIT), VO2Max,

\section{INTRODUCTION}

Sports activities are activities that will never lost from human life and as part of human education and development. Besides being a necessity for humans, sport is also a part of man himself, sport as physical activity in the form of games containing struggle and sportsmanship in the process of winning [1]. From this definition, there are three important elements in sports that are interrelated and inseparable. The three elements are physical activity, games, and organizational complexity [2].

Like other sports, futsal is a sport that requires good physical condition and excellent endurance in order to achieve maximum performance in every match. Futsal requires a very high team collectively, each player must continue to move without stopping to find space and seize the ball. In order to get successful in this team environment, a player must also have endurance. Endurance is one component of physical training that players must have in order to have high endurance when playing futsal. Physical training to improve endurance will be achieved by doing the training in a planned, measurable and sustainable manner over and over again.
High Intensity Interval Training (HIIT) or training with high intensity intervals marked by repeating relatively short sessions, high interval training, often done with an all-out effort or at an intensity close to what gives rise to peak oxygen absorption (that is $\geq 90 \%$ form VO2Max) [3]. The research journal states that high-intensity training has been suggested for aerobic and cardiovascular adaptation to be greater than at low and moderate levels [4,5]. High-intensity interval training makes an increase an oxidative muscle enzymes in a relatively short time of 1-2 weeks [6]. HIIT is a cardio training that uses a combination of high intensity training with moderate or low intensity within a certain time interval. For example, running a sprint for about 20-30 seconds and followed by walking or jogging for 40-90 seconds depending on the fitness conditions of each.[7,8]. This training is more effective and efficient, it does not require a long time but gives satisfying results $[9,10]$. HIIT can improve cardiorespiratory fitness (VO2Max) $4 \%$ until 46\% through 2 until 15 weeks training. This exercise can also increase VO2Max rapidly. HIIT has the effect to increase VO2Max and causes physiological thickening of the left ventricular myocardial heart so that the strength and ability of the heart to pump blood each contraction increases thereby reducing the number of beats per minute $[11,12]$.

This research wants to know effect of 8 weeks HIIT on VO2Max of student and increasing of VO2Max of student as extracurricular participant futsal through HIIT during 8 weeks. The quality of cardiorespiratory one of them endurance can be expressed by VO2Max, which is the maximum amount of oxygen that the body can consume in millilitres per kilogram (body weight), per minute $(\mathrm{ml} \cdot \mathrm{kg}-1 \cdot \mathrm{min}-1)[13,14]$. Beside that can be expressed with $2,4 \mathrm{Km}$ run and 12 minutes run. The greater VO2Max a person has, the more excellent physical fitness, where the quality of the biometric components is also getting better. The higher the value of VO2Max means the higher the body's ability to consume oxygen for metabolism. VO2Max is maximum aerobic capture represents the maximum amount of oxygen consumed per unit time by a person during training or tests, with heavier training until he is tired $[15,16]$. Thus the more amount of oxygen consumed by the player's body will be better for his muscles to do sports activities such as futsal and other sports. Then, the higher a player's VO2Max, the higher the endurance owned by the player. 


\section{RESEARCH METHODS}

Data analysis procedures will be performed pre-test, treatment and post-test, using test and measurement methods. At the twenty-sixth meeting a post-test was conducted, that is all participants returning to measure VO2Max using the test instrument of Multistage Fitness Test (MFT)/Beep test. The meeting is held within 3 times a week, for 8 weeks/ 2 months

Before testing the hypothesis, it is necessary to do a prerequisite test. Testing the measurement data related to the results of the study aims to help the analysis to be better. For this reason, this research will test normality and homogeneity data. In the process of data analysis the authors use the help of the Statistical Product and Service Solution 22 program (SPSS 22). To give meaning to the data generated from tests and measurements will be carried out as follows: 1) Test Prerequisite Analysis, 2) Test data normality using the Kolmogorov-Smirnov Test, and 3) Homogeneity test of variance uses Levine's test.

This study uses quasi-experimental methods. The design used in this study is "One-Group Pre-test Post-test Design". Place of research: 1) Pre-test and post-test were held in the hall of Budi Mulia Mangga Besar Elementary School, Budi Mulia School Complex, Jalan Mangga Besar Raya No. 135 Jakarta Pusat; 2) The High Intensity Interval Training (HIIT) were held: a) Field of Budi Mulia Mangga Besar Elementary School, b) Field of Budi Mulia Mangga Besar Junior High School and Senior High School, c) Taman Sari Stadium, Jalan Mangga Besar VI Selatan No.30, RT.8/RW.1, Taman Sari, Tamansari, Jakarta Barat.

The time of the pre-test research was January 21, 2019. While for starting the training research of High Intensity Interval Training (HIIT) is for 2 months ( 8 weeks) with a frequency of 3 times a week, from 11 February 2019 to 6 April 2019, and the post-test was held on 8 April 2019.

The this research population is all students who are active and routinely take part in futsal extracurricular training at Junior High School Budi Mulia Jakarta, totalling 24 people. The instrument in the form of this test can be used to measure basic abilities, and achievements. In this study the instrument used was Multistage Fitness Test (MFT)/Beep test [17].

Data analysis procedures will be performed pre-test, treatment and post-test, using test and measurement methods. The data collection mechanism is as follows: 1. Pre-test at the first meeting, all participants were measured VO2Max using test instruments of Multistage Fitness Test (MFT)/Beep test. 2. At the second to twenty-fifth meeting each participant starts the training using High Intensity Interval Training (HIIT).
TABLE I. TRAINING WITH HIGH INTENSITY INTERVAL TRAINING (HIIT)

\begin{tabular}{|l|l|}
\hline $\begin{array}{c}\text { 1 Week of Training } \\
\text { (repeated for 8 weeks) }\end{array}$ & \multicolumn{1}{c|}{ TYPES OF HIIT TRAINING } \\
\hline $\begin{array}{l}\text { Session I (Monday)/ } \\
\text { afternoon }\end{array}$ & $\begin{array}{l}\text { Stretching and warming up for 5 minutes } \\
\text { Sprint 20 seconds and jump kneetucks 6x, } \\
\text { t.r (recovery)/active rest 1: 1 } \\
\text { Cooling for 2 minutes }\end{array}$ \\
\hline $\begin{array}{l}\text { Session II (Thursday)/ } \\
\text { afternoon }\end{array}$ & $\begin{array}{l}\text { Stretching and warming up for 5 minutes } \\
\text { Sprint 20 detik dan jumping jack 10x, t.r } \\
\text { (recovery)/active rest 1: } \mathbf{1} \\
\text { Cooling for 2 minutes }\end{array}$ \\
\hline $\begin{array}{l}\text { Session III (Saturday)/ } \\
\text { morning }\end{array}$ & $\begin{array}{l}\text { Stretching and warming up for 5 minutes } \\
\text { Sprint 20 seconds and jogging, } \\
\text { t.r (recovery)/active rest 1: 1 } \\
\text { Cooling for 2 minutes }\end{array}$ \\
\hline
\end{tabular}

\section{RESULTS AND DISCUSSION}

The results of research that have been done show an increase in VO2Max after being treated for eight weeks. The mean of the final test was 31,4042 and the mean of the initial test was 28,9333. Thus, the difference from the mean shows an increasing after being treated during the eight week training and with a frequency of three times. From the two dependent variables as showed above, each improvement from the initial and final tests in this experiment can also be presented, then it can be clarified in the graph below.

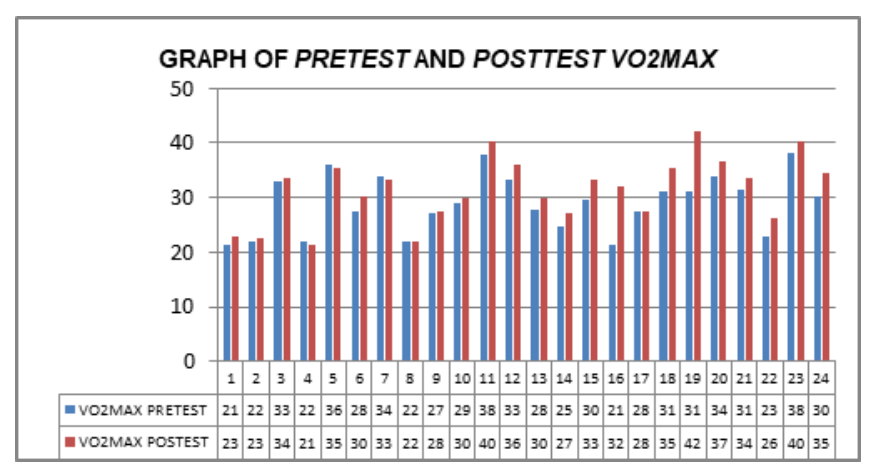

Fig. 1. Pre-test and post-test VO2Max.

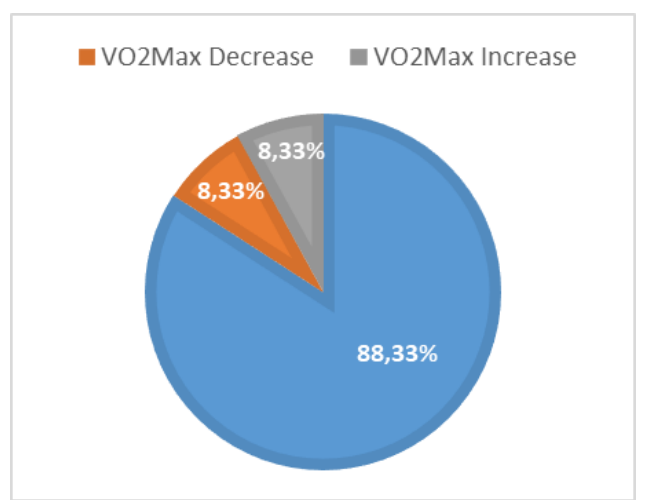

Fig. 2. Training effect diagram of HIIT toward VO2Max.

Obtaining maximum aerobic capacity data (VO2Max) that obtained from the figure above is the result of Beep Test/Multistage Fitness Test (MFT). This experiment showed an increasing in maximal aerobic capacity (VO2Max) on respondent, there are 20 participants of extracurricular or equal to $83,33 \%$, although $8,33 \%$ respondent have experienced 
decreasing of aerobic capacity (VO2Max) or 2 participants of extracurricular, that is no.4 (from 21,8 becomes 21,4 ) and no.5 (from 36 becomes 35,3) and 8,33\% respondents did not experience changes/did not experience an increase or decrease in aerobic capacity (VO2Max) or 2 extracurricular participants no. $8(22,1)$ and no.17 $(27,6)$. Thus from the graph above can be concluded that after the treatment of the training program of High Intensity Interval Training (HIIT) that is conducted for eight weeks with the frequency of training three times a week experienced the most increase in VO2Max result in loading.

To know the effect of High Intensity Interval Training (HIIT) Toward VO2Max, the testing step uses the t-test which in SPSS is called paired t-test. The results of data processing in the table below.

TABLE II. PAIRED SAMPLE TEST RESUlt (Uji T) SPSS 22 PAIRED SAMPLES TEST

\begin{tabular}{|c|c|c|c|c|c|c|c|}
\hline \multicolumn{5}{|c|}{ Paired Differences } & \multirow[b]{3}{*}{$\mathbf{t}$} & \multirow[b]{3}{*}{ df } & \multirow{3}{*}{$\begin{array}{l}\text { Sig. } \\
(2- \\
\text { tailed })\end{array}$} \\
\hline \multirow[b]{2}{*}{ Mean } & \multirow{2}{*}{$\begin{array}{c}\text { Std. } \\
\text { Deviation }\end{array}$} & \multirow{2}{*}{$\begin{array}{l}\text { Std. } \\
\text { Error } \\
\text { Mean }\end{array}$} & \multicolumn{2}{|c|}{\begin{tabular}{|c|}
$\begin{array}{c}\text { 95\% Confidence } \\
\text { Interval of the } \\
\text { Difference }\end{array}$ \\
\end{tabular}} & & & \\
\hline & & & Lower & Upper & & & \\
\hline 2.47083 & 2.98962 & .61025 & 1.20843 & 3.73324 & 4.049 & 23 & .000 \\
\hline
\end{tabular}

Based on the table above, there are differences before and after treatment of each dependent variable (VO2Max), which is the difference between the mean of VO2Max post-test and VO2Max pre-test as much 2,47083. While the amount of tcount is 4,049 and ttable with $\mathrm{dk} / \mathrm{df}$ (degree of freedom) 23 is 2,069. Likewise, the paired sample test number shows a significance of 0,000 so this indicates that the significance level of the variable is 0,000 or in other words p-value $<0.05$ which results in $\mathrm{H} 0$ being rejected and H1 accepted. Through the results of these calculations it can be concluded that there are differences after being given training of High Intensity Interval Training (HIIT).

To know an increasing VO2Max of student as extracurricular participant futsal in Junior High School Budi Mulia Jakarta can be known through the calculation of the difference in the pre-test average and post-test average, the results of the percentage increase are as follows:

TABLE III. INCREASING PERCENTAGE

\begin{tabular}{|c|c|c|c|}
\hline $\begin{array}{c}\text { Mean } \\
\text { Post- } \\
\text { test }\end{array}$ & $\begin{array}{c}\text { Mean } \\
\text { Pre-test }\end{array}$ & $\begin{array}{c}\text { Mean Difference } \\
\text { (Mean Poshest - } \\
\text { Mean Pre-test) }\end{array}$ & $\begin{array}{c}\text { Percentage } \\
\text { (Mean Df/Mean } \\
\text { Pre-test x100\%) }\end{array}$ \\
\hline 31.4042 & 28.9333 & 2.470833 & 8,54 \\
\hline
\end{tabular}

There is an increase in the maximum capacity of oxygen (VO2Max) based on the data above, which originally an average of 28.9333 increased to 31.4042 , there was a difference of 2.470833 . Then the calculation is done (mean difference: mean pre-test $\mathrm{x} 100 \%)$ that is $(2,470833: 28,9333 \mathrm{x}$ $100 \%)$. It can be seen that the percentage increase VO2Max of student as extracurricular participant futsal in Junior High School Budi Mulia Jakarta after given training of High
Intensity Interval Training (HIIT) during 8 weeks is as much $8,54 \%$.

Based on the data analysis results on the hypotheses in the research described above is known that there is a significant effect of High Intensity Interval Training (HIIT) toward increasing VO2Max of student as extracurricular participant futsal in Junior High School Budi Mulia Jakarta. This is indicated from the results of tcount $=4,049>$ ttable $=2,069$ and the big significance of paired sample test is 0,000 or in other word p-value is $<0,05$ that result if $\mathrm{H} 0$ is rejected and $\mathrm{H} 1$ is accepted. So it can be concluded that there are differences after being given High Intensity Interval Training (HIIT) for 8 weeks. To find out the percentage of increase VO2Max of student as extracurricular participant futsal in Junior High School Jakarta had been conducted the calculation (mean difference : mean pre-test $\mathrm{x} 100 \%)$ is $(2,470833: 28,9333 \mathrm{x}$ $100 \%$ ). Based on the results of the percentage calculation is obtained the increase VO2Max of student as extracurricular participant futsal in Junior High School Budi Mulia Jakarta as much $8,54 \%$.

High interval intensity training or HIIT is defined as the training that consists of several cycles of short or moderate duration and high intensity and every cycle is interspersed with rest periods in the form of light intensity training. Based on the results of the data analysis above, it can be concluded that the effort of increase VO2Max through High Intensity Interval Training (HIIT) gave an effect in increasing VO2Max of student as extracurricular participant futsal in Junior High School Budi Mulia Jakarta.

Based on the results of data analysis on the hypothesis in the research described above it is known that there is a significant effect of High Intensity Interval Training (HIIT) on the increase in VO2Max of futsal extracurricular participants in Budi Mulia Jakarta Middle School.

This is in line with research written by Aji entitled "The Effect of 8 Weeks of High Intensity Interval Training (HIIT) on VO2Max Active Individuals for Men 18-22 Years" The results of the study showed an increase in VO2Max namely $(19,66 \%)$ [18]. Through both studies it can be concluded that HIIT training has a significant effect on the increase in VO2Max.

\section{CONCLUSION}

The study concluded that there was an effect of the High Intensity Interval Training (HIIT) toward the increasing VO2Max of student as extracurricular participant futsal in Junior High School Budi Mulia Jakarta. The research results showed that there was an increase VO2Max of student as extracurricular participant futsal in Junior High School Budi Mulia Jakarta, after being given High Intensity Interval Training (HIIT) during 8 weeks. Because High Intensity Interval Training (HIIT) has an effect toward the increasing VO2Max, This research can be a guideline for futsal extracurricular practitioners in schools by providing High Intensity Interval Training (HIIT) programs to students with regular and continuous training patterns in order to achieve the objective of good VO2Max for improving futsal sports achievements. This is in line with research from Anda who 
[8] R. B. Viana et al., "Is interval training the magic bullet for fat loss? A systematic review and meta-analysis comparing moderate-intensity continuous training with high-intensity interval training (HIIT)," British Journal of Sports Medicine. 2019.

\section{IMPLICATIONS}

After 2 months of research the implications can be known, namely: that this HIIT study has a very significant effect so that HIIT training can be applied by trainers properly. This HIIT research offers a solution for the implementation of coaching in the club or in the extra-curricular. But the age of beginners is recommended not to use very high intensity

\section{REFERENCES}

[1] J. S. Ramos, L. C. Dalleck, A. E. Tjonna, K. S. Beetham, and J. S. Coombes, "The Impact of High-Intensity Interval Training Versus Moderate-Intensity Continuous Training on Vascular Function: a Systematic Review and Meta-Analysis," Sports Medicine. 2015.

[2] A. E. Smith-Ryan, M. N. Melvin, and H. L. Wingfield, "High-intensity interval training: Modulating interval duration in overweight/obese men," Phys. Sportsmed., 2015.

[3] G. Fisher et al., "High intensity interval- vs moderate intensity- training for improving cardiometabolic health in overweight or obese males: A Randomized controlled trial," PLoS One, 2015.

[4] A. Hannan et al., "High-intensity interval training versus moderateintensity continuous training within cardiac rehabilitation: a systematic review and meta-analysis," Open Access J. Sport. Med., 2018.

[5] K. Liou, S. Ho, J. Fildes, and S. Y. Ooi, "High Intensity Interval versus Moderate Intensity Continuous Training in Patients with Coronary Artery Disease: A Meta-analysis of Physiological and Clinical Parameters," Hear. Lung Circ., 2016.

[6] A. Sabag, A. Najafi, S. Michael, T. Esgin, M. Halaki, and D. Hackett, "The compatibility of concurrent high intensity interval training and resistance training for muscular strength and hypertrophy: a systematic review and meta-analysis," J. Sports Sci., 2018.

[7] M. E. Jung, J. E. Bourne, M. R. Beauchamp, E. Robinson, and J. P. Little, "High-intensity interval training as an efficacious alternative to moderate-intensity continuous training for adults with prediabetes," J. Diabetes Res., 2015.

[9] N. Naser, A. Ali, and P. Macadam, "Physical and physiological demands of futsal," Journal of Exercise Science and Fitness. 2017.

[10] M. Wewege, R. van den Berg, R. E. Ward, and A. Keech, "The effects of high-intensity interval training vs. moderate-intensity continuous training on body composition in overweight and obese adults: a systematic review and meta-analysis," Obesity Reviews. 2017.

[11] L. M. Ross, R. R. Porter, and J. L. Durstine, "High-intensity interval training (HIIT) for patients with chronic diseases," Journal of Sport and Health Science. 2016.

[12] S. A. Costigan, N. Eather, R. C. Plotnikoff, C. H. Hillman, and D. R. Lubans, "High-Intensity Interval Training for Cognitive and Mental Health in Adolescents," Med. Sci. Sports Exerc., 2016.

[13] K. Marcinko, S. R. Sikkema, M. C. Samaan, B. E. Kemp, M. D. Fullerton, and G. R. Steinberg, "High intensity interval training improves liver and adipose tissue insulin sensitivity," Mol. Metab., 2015.

[14] Ø. Sylta et al., "The effect of different high-intensity periodization models on endurance adaptations," Med. Sci. Sports Exerc., 2016.

[15] M. J. Gibala, "High-intensity interval training: New insights," Sport. Sci. Exch., 2007.

[16] B. J. Sawyer, W. J. Tucker, D. M. Bhammar, J. R. Ryder, K. L. Sweazea, and G. A. Gaesser, "Effects of high-intensity interval training and moderate-intensity continuous training on endothelial function and cardiometabolic risk markers in obese adults," J. Appl. Physiol., 2016.

[17] R. Instituto Brasileiro de Pesquisa e Ensino em Fisiologia do Exercício, M. F. da S. Cardoso, J. Cicero Moraes, G. dos S. Cunha, P. Eloi Gomes Voser, and M. L. Morais, Revista brasileira de futsal e futebol. 2017.

[18] Aji, Redyte Setio. (2017). "Pengaruh 8 Minggu Hingh Intensity Training (HIIT) Terhadap VO2Max Individu Aktif laki-Laki 18-22 Tahun". Abstrak Tugas akhir. Salatiga: Fakultas Kedokteran dan Ilmu Kesehatan Kristen Satya Wacana. (online) http: //repository.uksw.edu/bitstream/123456789/14282/2/T1_482013014_Ab stract.pdf. (diakses 28 Januari 2019)

[19] Y. Kilian, F. Engel, P. Wahl, S. Achtzehn, B. Sperlich, and J. Mester, "Markers of biological stress in response to a single session of highintensity interval training and high-volume training in young athletes," Eur. J. Appl. Physiol., 2016. 